\title{
УПРАВЛІННЯ ПРОЦЕСОМ ПІДВИЩЕННЯ ТЕХНОЛОГІЧНОСТІ ВИРОБІВ
}

\section{Вступ}

Виріб, перш за все, є об'єктом експлуатації і оцінюеться споживачами на відповідність своєму призначенню. Але, перш ніж стати об'єктом експлуатації, виріб виступае в якості об'єкту виробництва, до якого пред'являються зовсім інші вимоги, що в сукупності названі технологічністю. Тому до остаточного оформлення креслення конструктор повинен приступити лише після того, як у нього з'явиться упевненість не тільки в експлуатаційних якостях виробу, але і в його технологічності, тобто в можливості його якісного виготовлення в конкретних виробничих умовах.

Остаточна перевірка технологічності виробу проводиться в період завершення конструкторських робіт, випробування і аналізу дослідних зразків виробу. Це остання можливість зміни конструкції без серйозного втручання в плани освоєння. Вартість перегляду проекту на цьому етапі значно менше ніж внесення змін пізніше ? при виготовленні або експлуатації виробу.

Нерідкі випадки, коли конструктору після зауважень технолога доводиться не тільки допрацьовувати, але і спочатку переробляти конструкцію. Як правило, спроби технологів вносити більш менш серйозні зміни в конструкцію наражаються на заперечення конструкторів, які посилаються на те, що переконструювання окремих деталей веде до переробок вже повністю розроблених виробів.

На практиці підприемств часто зустрічаються випадки, коли вимоги технолога, що пред'являються до технологічності деталі на етапі технологічного контролю конструкторської документації, які спочатку не були прийняті конструкторами, доводиться вносити в креслення вже після того, як виріб було запущено у виробництво. Тому конструкція може вважатися завершеною лише після ретельного розгляду і узгодження ï з технологами. Задача фахівця, який здійснюе технологічний контроль, полягає в своєчасній допомозі конструктору у відпрацюванні виробу на технологічність.

Яким би досвідченим ні був технолог, один він не завжди може знайти найдоцільніше технологічне рішення. Тому колективне обговорення найістотніших, принципових моментів виготовлення і колективний вибір оптимального варіанту рішення повинні бути рекомендовані при розробці технологічних процесів.

Відпрацювання нового виробу на технологічність е комплексним вивченням нової конструкції фахівцями всіх підрозділів системи виробництва. Це прискорюе доведення всіх елементів конструкції з погляду ії призначення, надійності, вартості і зовнішнього вигляду.

(c) О.А. Стенін, С.В. Лапковський, М.О. Солдатова, 2010 
До теперішнього часу існують великі труднощі при технологічному контролі конструкторської документації, оскільки дотепер не вироблені конкретні практичні рекомендації технологу для його виконання.

Аналіз існуючих систем відпрацювання на технологічність виробів, що проектуються на підприемстві, показав, що вивчення конструкторської документації, послідовність її відпрацювання дотепер методично розроблені слабо. На стадії науково-дослідних робіт відпрацювання на технологічність поверхневе. Основна важкість відпрацювання лягає на стадію технологічної підготовки, на яку відводиться обмежений час, за який технологи встигають розробити і оформити тільки один варіант технології. Такий стан справ призводить до низької якості технологічних рішень, і вся важкість по остаточному відпрацювання на технологічність лягає на останню стадію ? освоєння виробу в цеху, коли вже виготовлено технологічне оснащення. Будь-яка зміна в конструкторськотехнологічній документації на даній стадії призводить до додаткових витрат, які пов'язані з корегуванням, а, у багатьох випадках, і з проектуванням технологічного оснащення заново і його виготовленням вже в аварійному порядку, що вкрай негативно позначається на витратах $\mathrm{i}$ термінах освоєння виробів.

Треба визнати, що, не дивлячись на те, що відпрацювання нового виробу на технологічність $є$ дуже важливою проблемою і без нього просто неможливе існування будь-якого сучасного виробництва в галузі приладота машинобудування, аналіз літературних джерел вказуе на те, що до теперішнього часу немає єдиної відпрацьованої системи, єдиних методологічних основ відпрацювання виробів на технологічність. Так, мабуть, у [1] наведена найбільша кількість публікацій (понад 5000), що пов'язані з поняттям технологічності. Інформація, яка наведена у більшості з цих публікацій, підтверджуе вищесказане.

В залежності від виду виробу і галузі виробництва, підходи до питання відпрацювання нового виробу на технологічність дуже різняться між собою, що може підтвердити аналіз літературних джерел [2 - 13]. Особливо слід зауважити, що якщо методологію відпрацювання на технологічність у таких галузях, як ливарне виробництво і механічна розробка, можна вважати достатньо розвиненою, то про такі галузі, як складання (особливо роботизоване) та автоматизація, цього сказати ніяк не можна.

Взагалі, питанню відпрацювання нових виробів на технологічність у складальному виробництві, а також в умовах автоматизації та роботизації присвячено дуже мало праць. До таких, скоріше за все, можна віднести лише деякі фрагменти з [3-6, 8, 9].

\section{Постановка задачі}

Сукупність властивостей виробу, що визначають пристосованість його конструкції до досягнення оптимальних затрат ресурсів при виробництві і експлуатації для заданих показників якості, об’ему випуску і умов виконання робіт, є технологічністю конструкції виробу (ТКВ). 
Розробка нового виробу - складна конструкторська задача, що пов'язана не тільки з досягненням необхідного технічного рівня цього виробу, але і з наданням його конструкції таких властивостей, які забезпечують максимально можливе зниження затрат праці, матеріалів і енергії на його розробку, виготовлення, технічне обслуговування і ремонт. Рішення цієї задачі визначається діловою творчою співдружністю творців нової техніки - конструкторів і технологів — i їх взаємодією на етапах розробки конструкції виробу з його виготовлювачами і споживачами. Першорядна роль в забезпеченні ТКВ належить конструктору, який повинен керуватися міркуваннями як технічної, так і економічної доцільності проектованої конструкції, вміти використовувати такі інженерні рішення, які забезпечують досягнення необхідних технічних показників виробу при раціональних затратах ресурсів, що виділяються на його створення і використання.

Стадія розробки виробу грає визначальну роль у визначенні вимог до забезпечення ТКВ, оскільки для кожної стадії характерні своєрідна цільова установка, відмінні від інших стадій глибина конструкторського пророблення технічних рішень і ступінь укрупнення їх технікоекономічних оцінок.

Розробка виробу - складний, багатоступеневий процес, для якого характерні три чітко виражені фрази:

- перша фраза (розробка технічного завдання) - процес встановлення вихідних вимог і формування попередніх (можливих і бажаних) контурів об'єкту розробки;

- друга фраза (розробка проектної конструкторської документації) процес послідовно поглиблюваного техніко-економічного пророблення інженерних рішень, який здійснюеться, виходячи з даних технічного завдання, результатів науково-дослідних робіт і практичного досвіду;

- третя фраза (розробка робочої конструкторської документації) - процес матеріального втілення результатів інженерного пошуку, систематизації дослідницько-промислових даних і співставлення їх з технічним завданням, внесення необхідних уточнень в документацію.

До другої фрази, залежно від новизни і складності конструкції виробу, можуть бути віднесені:

- багатократне (багатоваріантне) моделювання об’єкту в документації, співставлення і аналіз різних моделей, заснованих на поєднанні різних за новизною, складністю і іншим ознакам складових елементів, і виділення оптимального варіанту (розробка технічної пропозиції);

- пророблення і вивчення основних складових елементів оптимального варіанту моделі об’єкту і принципів їх взаємодії (розробка ескізного проекту);

- всебічне пророблення моделі об'єкту, всіх їі елементів і їх взаємозв'язків, що дозволяє отримати повне уявлення про будову і принцип 
роботи об'єкту і ухвалити остаточні технічні рішення за вихідними матеріалами, складом і структурою виробу (розробка технічного проекту).

Виріб, як і будь-який продукт праці, призначений для задоволення певних потреб, володіє властивостями, які утворюють його якість.

Конструктор, надаючи конструкції виробу в процесі її розробки необхідні властивості, що виражають корисність виробу, надаєїй і такі конструктивні властивості, які зумовлюють рівень затрат ресурсів на створення, виготовлення, технічне обслуговування і ремонт виробу. Ці властивості виробу в цілому і визначають технологічність.

ТКВ відображає не функціональні властивості виробу, а його конструктивні особливості. В загальному випадку конструкцію виробу характеризують склад і взаємне розташування його складових частин, схема пристрою виробу в цілому, форма і розташування поверхонь деталей і з'єднань, їх стан, розміри, матеріали і інформаційна виразність.

Якість виробу разом з технологічністю конструкції характеризуеться в загальному випадку також його функціональністю (здатністю виробу реалізовувати основну функцію для досягнення заданого технічного ефректу), надійністю, ергономічністю, естетичністю, економічністю, безпекою і екологічністю.

Перераховані грані якості виробу обумовлені значною мірою його конструктивним виконанням, яке, у свою чергу, визначає технологічність конструкції виробу в цілому.

Зв'язок технологічності з іншими властивостями конструкції виробу реалізуеться в сфрерах її прояву у формі вирішення протиріч між активними елементами технологічного процесу 一 людиною і знаряддями праці, що використовуються нею, з одного боку, і протидіючим елементом предметом праці (виробом, його моделлю або заготовкою), з іншого.

3 системних позицій слід розрізняти три види протидій виробу, його моделі або заготовки активним елементам процесів виготовлення, експлуатації і ремонту:

- субстантні - що обумовлені матеріально-речовим складом виробу;

- структурні - що обумовлені особливостями конструктивної форми його виконання;

- фрункціональні - що пов'язані з різноманітністю умов виконання робіт при наданні виробу певної форми або вмісту в процесах виготовлення, а також при підтримці або відновленні його якості в процесах експлуатації або ремонту.

Субстантні протидії виробу, перш за все, виявляються в елементарних основах: його ваги - різним переміщенням; властивостей його матеріалу — різанню або тиску; його маси - через інерційні сили - виконанню деяких механічних і складальних робіт тощо.

Структурні протидії виробу активним елементам процесів виготовлення, експлуатації і ремонту обумовлені складністю конструкції і її еле- 
ментів, розташуванням і доступністю для обробки, жорсткістю конструкції, числом складових частин тощо.

Функціональні протидії виробу умовам виконання робіт в різних сфрерах визначаються об'ємом випуску виробів і типом виробництва, його регулярністю і стабільністю, а також специфічними вимогами до конструкції виробу, дотримання яких викликано необхідністю надання виробу певних властивостей естетичності і ергономічності і дотримання вимог техніки безпеки, виробничої санітарії і охорони навколишнього середовища.

При аналізі процесів розробки конструкції виробу враховуеться їх взаемозв'язок із сферами прояву їі властивостей, включаючи наукові дослідження і розробки нових процесів, технологічних методів і засобів, процеси виробництва, експлуатації і ремонту виробу (рис. 1).

Показники призначення (технічного ефекту) характеризують відповідність виробу умовам реалізації його основних функцій. Їх співвідношення з витратами всіх видів ресурсів визначає ефективність техніки, яка створюеться і експлуатується. У ряді випадків здатність виробу виконувати свої основні функції безпосередньо визначається його конструктивним виконанням. Це накладає істотне обмеження на вибір технологічно раціональних інженерних рішень, що приймаються відносно конструкції виробу в період його розробки. Але і в цих випадках можлива багатоваріантність рішень, а, отже, і вибір найраціональнішого з них.

Вимоги до надійності (безвідмовності, довговічності, ремонтоздатності і зберігання) спрямовані на забезпечення виконання виробом заданих функцій в процесі експлуатації шляхом збереження в часі і у встановлених межах значень всіх параметрів, що характеризують здатність виконувати ці функції в певних режимах і умовах застосування, технічного обслуговування, ремонту, зберігання і транспортування. Реалізація цих вимог в конструкції виробу спричиняе за собою трудові, матеріальні і енергетичні витрати на виробництво виробу, підтримку і відновлення його працездатності в процесі технічного обслуговування і ремонту і тому повинна супроводжуватися заходами щодо забезпечення ТКВ.

Слід також враховувати безпосередній зв'язок показників надійності з показниками ТКВ. Наприклад, коефіцієнт нормування надійності залежить від витрат на планово-профілактичні роботи за термін служби виробу, загальна величина витрат пов'язана з числом відмов виробу в процесі його функціонування тощо.

Ергономічні властивості конструкції виробу аналогічно властивостям, які створюють ТКВ, виявляються як при виробництві, так і при експлуатації виробу в результаті фрункціонування складної системи виду людина - предмет праці або людина - виріб.

При проектуванні виробів також враховуеться необхідність взаємозв'язаного виконання заходів щодо надання конструкції виробу властивостей ергономічності і технологічності.

Художньо-конструкторське вирішення форми виконання виробу органічно пов'язано із забезпеченням ТКВ, пошуком оптимального (за рів- 


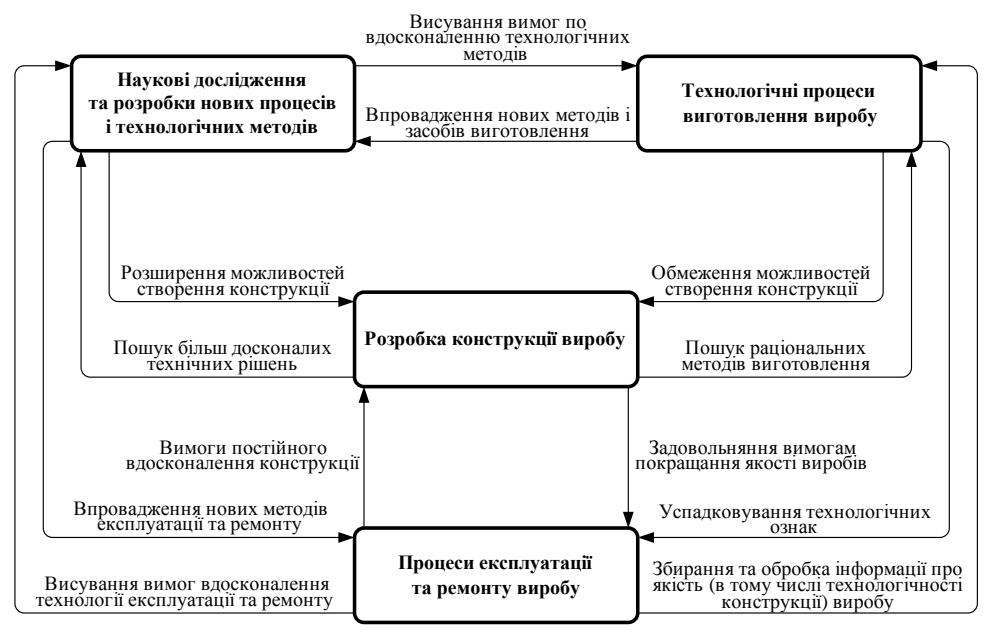

Рис. 1 - Структура взаємозв'язку процесів розробки конструкції виробу

нем витрат) поєднання раціональних в естетичному відношенні конструктивних форм виробу і технологічно раціонального конструктивного виконання виробу і його складових частин.

Надання конструкції виробу естетично і технологічно раціональних форм - двоєдина задача процесу конструювання. Заходи щодо забезпечення ТКВ в даному випадку проводяться в об'ємі, який продиктований необхідністю надання конструкції виробу естетичних властивостей.

Під економічністю виробу слід розуміти здатність виробу виконувати задані фрункції при використовуванні виділених для його функціонування матеріальних, енергетичних і інших ресурсів в об'ємах, відповідних встановленим для цієї мети нормам. До складу цих ресурсів не включаються оперативні витрати на технічне обслуговування і ремонт виробу, що характеризують експлуатаційну технологічність його конструкції. В цьому полягає істотна відмінність економічності виробу від експлуатаційної ТКВ. Проте ресурси, затрачувані в першому і другому випадках, входять в суму загальних експлуатаційних витрат на функціонування виробу і підтримці його в працездатному стані, що важливо враховувати при розрахунку узагальненого показника якості виробу.

В той же час для якісної характеристики ТКВ не слід застосовувати термін “економічність конструкції виробу”, оскільки економічність є загальною характеристикою фрунціонуючого виробу.

Техніка, що розробляеться людиною, знаходиться з ним в постійній взаємодії, тому разом із задоволенням його потреб за розглянутими вище властивостями вона повинна бути безпечною при виготовленні, транспортуванні, зберіганні, монтажі, підготовці до функціонування, техні- 
чному обслуговуванні, ремонті і утилізації, тобто, в усіх сферах, в яких виявляється і ТКВ. Надаючи конструкції виробу властивості, що становлять її технологічність, необхідно враховувати, що разом з цим, конструкція є носієм властивостей безпеки виробу.

Рівень шкідливих дій техніки на оточуюче середовище, які виникають при її виробництві, експлуатації і ремонті, залежить від тих, що приймаються при розробці конструкції виробу інженерних рішень по тих, що використовуються для його виготовлення, фрункціонування і відновлення робочим матеріалам, способам їх переробки, застосуванню в конструкції захисних пристроїв тощо. Ці рішення безпосередньо впливають на витрати ресурсів у всіх областях прояву ТКВ, тому забезпечення ТКВ і стійкості екологічної системи, у взаємодії з якою виріб повинен проявляти свої властивості, слід також розглядати як комплексну задачу створення виробу високої якості.

До багатьох видів виробів пред'являють вимоги до їх транспортабельності. Транспортабельність виробу характеризує його пристосованість до переміщення в просторі, що не супроводжується використовуванням виробу, а також до підготовчих і заключних операцій, які пов'язані з транспортуванням виробу в сфрерах його виробництва, експлуатації і ремонту. Чинники, що визначають транспортабельність виробу (маса і об'єм виробу, його габаритні розміри, режими переміщення, сприйнятливість до зовнішніх дій), істотно впливають на розміри витрат праці, матеріалів і енергії за заданих умов виконання робіт у всіх сорерах прояву ТКВ. Тому забезпечення транспортабельності виробу слід розглядати як складову частину робіт по забезпеченню ТКВ.

\section{Відпрацювання конструкції виробу на технологічність}

Відпрацювання конструкції виробу на технологічність здійснюеться безпосередньою дією на її технічну сутність шляхом надання конструкції

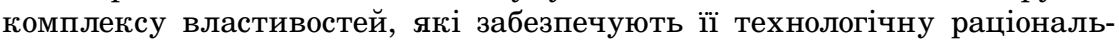
ність і спадкоємність. Наслідком цієї дії є зміна трудомісткості, матеріаломісткості, енергоємності або інших можливих видів ресурсомісткості виробу (рис. 2).

Ці види ТКВ, у свою чергу, виявляються в одній або декількох конкретних областях, утворюючи різновиди ТКВ по області прояву. Конструктор, надаючи конструкції виробу технологічну раціональність і спадкоємність в процесі відпрацювання її на технологічність, повинен враховувати одночасно можливі області прояву ТКВ, вплив інженерних рішень, що їм приймаються для зниження ресурсомісткості і підвищення рівня ТКВ по кожній області їі прояву з урахуванням результатів вдосконалення умов виконання робіт при виробництві, експлуатації і ремонті виробу.

До складу робіт із забезпечення ТКВ входять різноманітні заходи щодо досягнення технологічної раціональності і оптимальної спадкоємності конструкції виробу, які переважно спрямовані на досягнення наступних цілей: 


\section{ЗАБЕЗПЕЧЕННЯ ТЕХНОЛОГІЧНОСТІ КОНСТРУКЦІї ВИРОБУ}

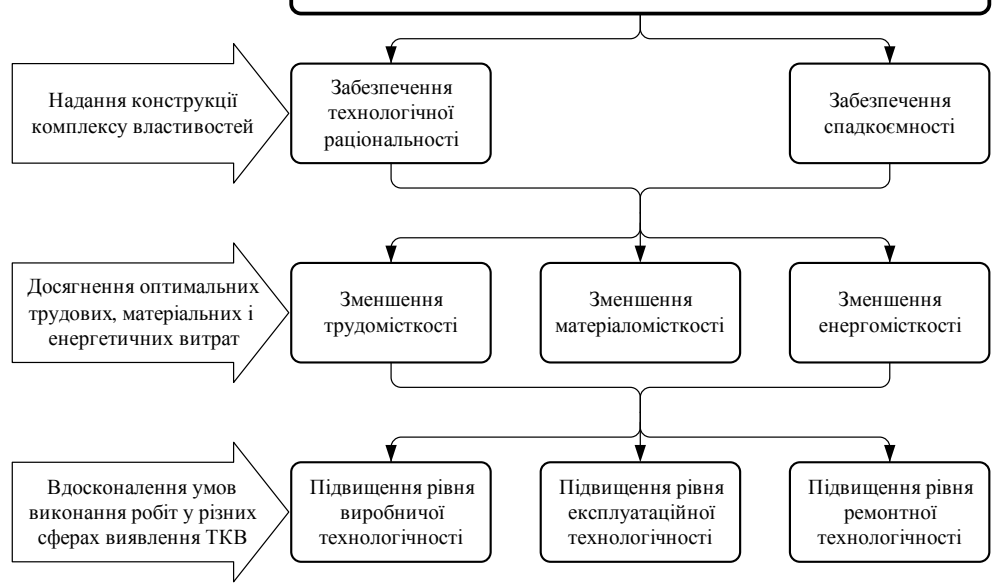

Рис. 2 - Схема зв'язків робіт із забезпечення ТКВ

- зниження трудомісткості і технологічної собівартості виробу у виготовленні і монтажі поза підприемством-виготовлювачем;

- зниження трудомісткості і технологічної собівартості виробу в експлуатації та ремонті і тривалості технічного обслуговування та ремонту виробу;

- зниження матеріаломісткості i енергоємності виробу, i, перш за все, їх найважливіших складових - витрат металу i паливно-енергетичних ресурсів при виготовленні, монтажі поза підприемством-виготовлювачем, технічному обслуговуванні і ремонтi.

Основний склад робіт із забезпечення ТКВ на стадіях розробки проектної та робочої конструкторської документації наведено на рис. 3 .

Відпрацювання конструкції виробу на технологічність при виконанні дослідно-конструкторських робіт доцільно проводити на основі комплексного використання спеціальних методів і прийомів конструювання, які забезпечують технологічну раціональність і спадкоємність конструкції виробу.

Під оцінюванням ТКВ мається на увазі комплекс взаємопов'язаних заходів, що включають послідовне виявлення ТКВ в цілому або окремих іiї властивостей, співставлення виявлених властивостей даного виробу із властивостями виробу, конструкція якого прийнята в якості бази для порівняння, і подання результатів співставлення у формі, яка прийнятна для ухвалення управлінських рішень по вдосконаленню конструкції виробу, що розробляеться. 


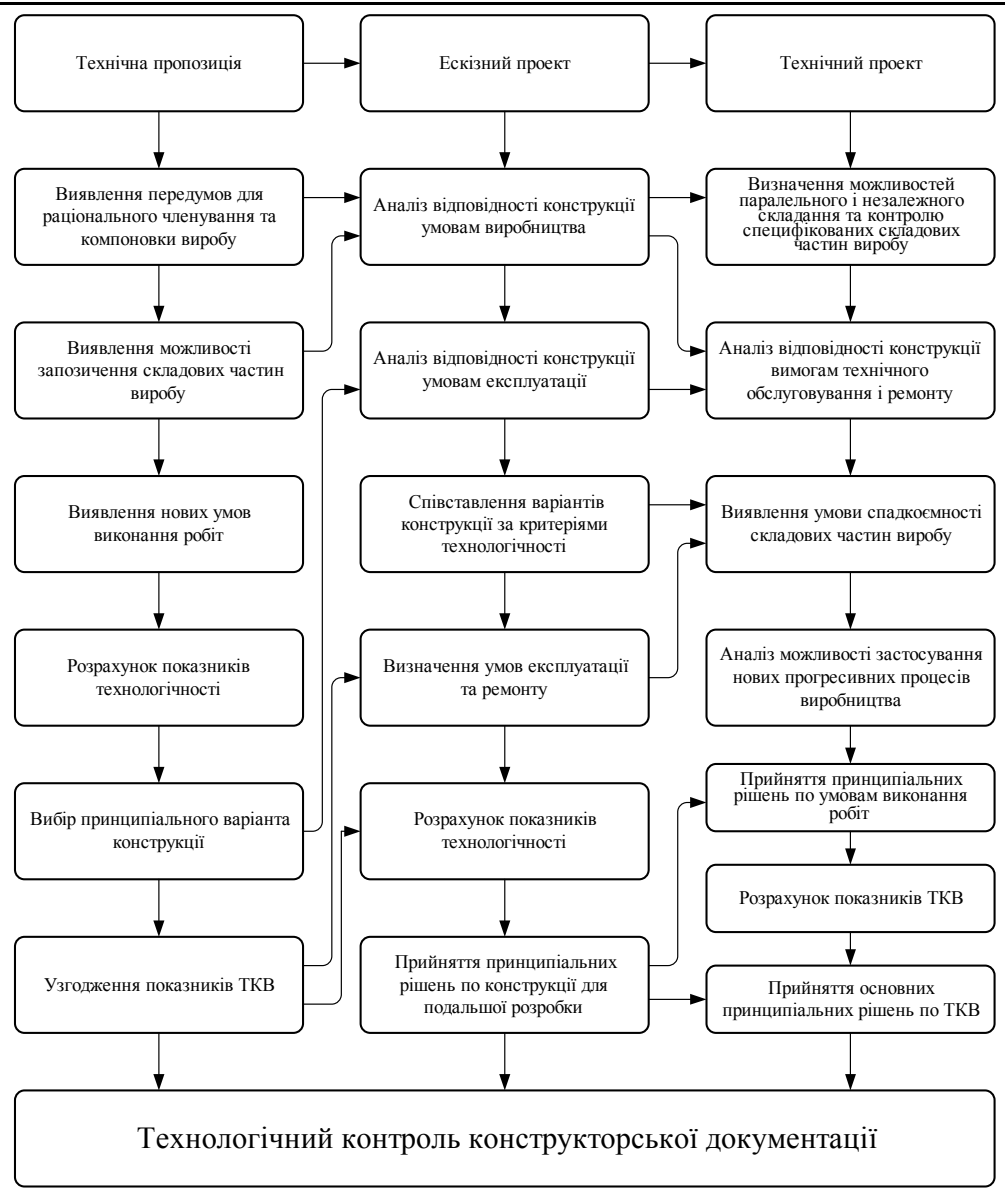

Рис. 3 - Основний склад робіт із забезпечення ТКВ на стадіях розробки проектної та робочої конструкторської документації

Залежно від методів оцінювання, що використовуються, розрізняють кількісне і якісне оцінювання ТКВ. Залежно від засобів оцінювання, що використовуються, розрізняють інженерно-розрахункові і інженерновізуальні методи оцінювання ТКВ.

Кількісне оцінювання ТКВ засноване на інженерно-розрахункових методах і проводиться за конструктивно-технологічними ознаками, які істотно впливають на виконання основних вимог до неї. Дане оцінювання ТКВ може проводитися за планованими показниками, коли виріб розробляеться за самостійним технічним завданням, яким встановлені 
базові показники ТКВ, і за непланованими показниками - при виникненні альтернативи ТКВ для вибору кращого конструктивного рішення з ряду рівноцінних за даними властивостями.

Необхідність кількісного оцінювання технологічності конструкції проектованого виробу, а також номенклатура показників і методика їх визначення встановлюються залежно від виду виробу, типу виробництва і стадії розробки конструкторської документації. При цьому число показників повинно бути мінімальним, але достатнім для оцінювання технологічності.

Кількісне оцінювання виробничої ТКВ проводиться незалежно від абсолютної величини витрат на виготовлення виробу, які обумовлені його конструкцією. Кількісне оцінювання експлуатаційної і ремонтної ТКВ проводиться при витратах на експлуатацію і ремонт, що зіставні із витратами на його виробництво або перевищують їх.

Оцінці ТКВ передуе комплекс заходів, що засновані на стандартизації (впорядкуванні) множини інженерних рішень. До таких рішень відносяться:

- оптимізація параметричних і типорозмірних рядів виробів як об'єктів виробництва і експлуатації;

- типізація конструктивних компоновок виробів;

- класифікація виробів і їх складових частин за конструктивними i технологічними ознаками;

- групування однотипних об'єктів класифікації і встановлення для кожної класифікаційної групи базових показників ТКВ.

Інженерно-розрахунковий метод оцінювання ТКВ являе собою сукупність прийомів, за допомогою яких розробник конструкції визначае $\mathrm{i}$ розрахунковим шляхом співставляе чисельні значення показника ТКВ проектованого виробу $K$ з відповідним показником конструкції виробу $K_{\sigma}$, який прийнятий в якості бази для порівняння.

Результатом кількісного оцінювання ТКВ із використанням інженерно-розрахункових методів оцінювання е формування цільової функції $Z$ і алгоритму забезпечення ТКВ, що придатні для ухвалення рішень по вдосконаленню конструкції виробу.

\section{Висновки}

Система забезпечення технологічності конструкції виробу повинна передбачати можливість ухвалення рішень як по конструкції виробу, так і по умовам його виробництва, експлуатації і ремонту вже на ранніх стадіях проектування. Забезпечення конструктивної і технологічної спадкоємності полегшуе задачу створення конструкції виробу, оскільки упорядковує склад етапів підготовки виробництва і скорочує терміни останньої.

\section{Література}

1. Альшиц И.Я., Благов Б.И. Проектирование деталей из пластмасс. Машиностроение. 1977. - 215c. 
2. Асфаль Р. Роботы и автоматизация производства/ Пер. с англ. М.Ю. Евстигнеева и др. - М.: Машиностроение, 1989. - 448 с.

3. Гибкие производственные системы, промышленные роботы, робототехнические комплексы. В 14 кн. Кн. 13. В.Н. Давыгора. ГПС для сборочных работ: Практ. пособие/ Под ред. Б.И. Черпакова. - М.: Высш. шк., 1989. - 110 с.

4. Гибкие сборочные системы/ Под ред. У.Б. Хегинботама; Пер. с англ. Д.Ф. Миронова; Под ред. А.М. Покровского. - М.: Машиностроение, 1988. - $400 \mathrm{c}$.

5. Замятин В.К. Технология и автоматизация сборки. - М.: Машиностроение, 1993. - $464 \mathrm{c}$.

6. Михлин В.М., Диков К.И., Стариков В.М. Эксплуатационная технологичность конструкции тракторов. - Машиностроение. 1982. $253 \mathrm{c}$.

7. Мысловский Э.В. Промышленные роботы в производстве радиоэлектронной аппаратуры. - М.: Радио и связь, 1988.-224 с.

8. Робототехнические системы в сборочном производстве/ Под ред. Е.В. Пашкова. - К.: Вища шк. Головное изд-во, 1987. — 272 с.

9. Технологичность авиационных конструкций, пути повышения. Часть1: Учебное пособие/ И.М. Колганов, П.В. Дубровский, А.Н. Архипов ? Ульяновск: УлГТУ, 2003. - 148 с.

10. Технологичность конструкции изделия: Справочник/ Под ред. Ю.Д. Амирова. - М.: Машиностроение, 1985. - 368 с.

11. http://elibrary.ru/query_results.asp

Отримано 18.02.2010 p. 